\title{
Genistein Inhibits Intestinal Cell Proliferation in Piglets
}

\author{
AN-CHIAN CHEN, MARK A. BERHOW, KELLY A. TAPPENDEN, AND SHARON M. DONOVAN \\ Division of Nutritional Sciences [A.-C.C., K.A.T., S.M.D.], University of Illinois at Urbana-Champaign, \\ Urbana, IL 61801; and United States Department of Agriculture [M.A.B.], Agricultural Research Service, \\ National Center for Agricultural Utilization Research, Peoria, IL 61604
}

\begin{abstract}
Currently $15 \%$ of U.S. infants are fed soy formulas that contain up to $14 \mathrm{mg}$ of genistein equivalents/L. Our goal was to investigate the impact of dietary genistein on intestinal development. Piglets ( $n=8$ /group) were fed sow milk replacer (MR), $\mathrm{MR}+1 \mathrm{mg} / \mathrm{L}$ of genistein (LG), or MR $+14 \mathrm{mg} / \mathrm{L}$ of genistein (HG) for $10 \mathrm{~d}$. Formula intake, weight gain, and intestinal length and weight were similar in all groups. Average serum genistein concentration in the HG group was similar to that of soy formula-fed infants. No significant effects of genistein on enterocyte apoptosis, lactase, and sucrase activities or electrophysiologic measures were observed in jejunum or ileum. Jejunal and ileal villus heights were not significantly different, but the percentage of proliferating cell nuclear antigen-positive jejunal crypt cells in the HG was reduced 50\% compared with that in MR and LG ( $p$ $=0.001$ ), indicating decreased proliferation. Enterocyte migration distance in the HG group tended to be $20 \%$ less $(p=0.1)$ than LG or MR. Jejunal estrogen receptor $\beta$ mRNA expression in HG was half of that in LG $(p=0.05)$, but neither was significantly different from MR. In conclusion, genistein at the level
\end{abstract}

\section{ABSTRACT}

present in soy infant formula is bioactive in the small intestine and results in reduced enterocyte proliferation and migration. The lack of effect of genistein on nutrient transport and enzyme activity suggests that the impact of genistein is greater on proliferating versus differentiated intestinal cells. (Pediatr Res 57: 192-200, 2005)

$\quad$ Abbreviations
BrdU, 5'-bromodeoxyuridine
ER, estrogen receptor
HG, high genistein
ITF, intestinal trefoil factor
LC-MS, liquid chromatography-mass spectrometry
LG, low genistein
LPH, lactase phlorizin hydrolase
MR, milk-replacer
PCNA, proliferating cell nuclear antigen
SP, spasmolytic polypeptide
TFF, trefoil factor

Soy infant formulas have been widely used as an alternative for infants with cow milk allergy and lactose intolerance for nearly 40 y $(1,2)$. Currently, $25 \%$ of formula-fed infants, or $15 \%$ of all infants, in the United States are fed soy-protein formulas $(2,3)$. Soy formulas contain $32-47 \mathrm{mg}$ of isoflavones/L, compared with $\sim 6 \mu \mathrm{g} / \mathrm{L}$ in breast milk (4-6). On the basis of an average formula intake of $900-1000 \mathrm{~mL} / \mathrm{d}$, a 4-mo-old infant who is fed soy formula consumes $28-47 \mathrm{mg}$, or $6-9 \mathrm{mg} / \mathrm{kg}$ body weight, of isoflavones per day (4). Approximately $60-65 \%$ of the isoflavones in soy formula are

Received March 30, 2004; accepted July 14, 2004.

Correspondence: Sharon M. Donovan, Ph.D., R.D., 457 Bevier Hall, 905 S. Goodwin Avenue, Urbana, IL 61801; e-mail: sdonovan@uiuc.edu

This research was funded by the State of Illinois through the Illinois Council on Food and Agricultural Research.

Presented in part at Experimental Biology 2003, April 2003, San Diego, CA [Chen A-C, Berhow MA, Tappenden KA, Donovan SM (2003) Genistein at a concentration present in soy infant formula inhibits intestinal cell proliferation in piglet. (abstract) FASEB J 17:A307].

DOI: 10.1203/01.PDR.0000150723.87976.32 present as genistin and genistein. Lactase phlorizin hydrolase (LPH; E.C. 3.2.1.23 and 62) is abundant in the neonatal small intestine (7) and can hydrolyze genistin to genistein (8), the latter of which is a biologically active phytoestrogen (5). Infants as young as $4 \mathrm{wk}$ of age are able to digest, absorb, and excrete genistein and daidzein as efficiently as adults (6). Genistein and other isoflavones are taken up by the enterocytes and are glucuronidated during first-pass uptake (9). Circulating genistein concentrations in infants who are fed soy formula is 2-fold higher than the peak serum genistein concentration obtained in adults who consumed a 50-mg single bolus of genistein (4,10). Although genistein is well absorbed, a small percentage of genistein remains in the enterocyte. The genistein that remains in the intestinal tissue is present as glucuronidated genistin and aglycone genistein $(11,12)$ and can amass to sufficient levels in intestinal cells to affect cell-cycle dynamics (13).

The impact of exposure to high doses of genistein on neonatal intestinal development has received very little atten- 
tion despite the presence of estrogen receptors (ERs) on intestinal cells (14-16) and the high rate of cell proliferation among the intestinal crypt cells (17). High concentrations of genistein inhibit proliferation of cancer cells $(18,19)$, whereas low concentrations of genistein stimulate proliferation of ER-positive cancer cells $(18,20,21)$. Thus, the physiologic effects of genistein are concentration dependent. Recent work in our laboratory supports a biphasic effect of genistein on intestinal cell-cycle dynamics (22). Low doses of genistein increased cell proliferation, whereas high concentrations of genistein, similar to those present in soy infant formula, induced cell-cycle arrest and reduced proliferation and cell number (22). Thus, in vitro data suggest that the proliferation of intestinal cells of soy formula-fed infants could be adversely affected.

The objective of the current study was to assess the impact of ingested genistein on intestinal structure and function in vivo using the piglet as the animal model for the human infant. The piglet and the human infant have a similar intestinal anatomy and digestive physiology (23). The newborn piglet is of similar size to the newborn human infant, and its rapid growth rate allows for the effects of the experimental treatment to be observed over shorter periods of time (24), supporting the use of the piglet as an animal model to study the human infant's digestive tract development and maturation. Our hypothesis was that consumption of genistein at the concentration that could be produced from genistin at the level currently contained in soy infant formula would adversely affect intestinal structure and function, whereas a low concentration of genistein would promote intestinal proliferation.

\section{METHODS}

Study design and diets. The Institutional Animal Care and Use Committee at the University of Illinois approved the animal protocol. Piglets $(n=24)$ were obtained within $48 \mathrm{~h}$ of birth, transported to the animal facilities, and housed individually in temperature- and light-controlled rooms as described by Houle et al. $(25,26)$. Piglets were distributed into three groups by litter $(n=$ 8/group): 1) medicated sow milk replacer (MR; control; Advance Baby-Pig LiquiWean, Dundee, IL); 2) MR + $1 \mathrm{mg} / \mathrm{L}$ of genistein [low genistein (LG)]; or 3) $\mathrm{MR}+14 \mathrm{mg} / \mathrm{L}$ genistein [high genistein (HG)]. Genistein (L.C. Laboratories, Woburn, MA) was dissolved in DMSO to give a stock concentration of 10 and $140 \mathrm{~g} / \mathrm{L}$. Genistein or an equivalent volume of DMSO was added to the formula immediately before feeding. Milk replacer $(183 \mathrm{~g} / \mathrm{L})$ was provided daily at a rate of $360 \mathrm{~mL} / \mathrm{kg}$ body weight divided into three feedings. Piglets self-fed from a nipple that was attached to tubing that was connected to an enteral nutrition bag that contained the diets $(25,26)$. A tray located under the nipple collected any spillage, allowing for accurate determination of formula and genistein intake. Forty-eight hours before the killing, $50 \mathrm{mg} / \mathrm{kg}$ body weight of 5'-bromodeoxyuridine (BrdU; Sigma Chemical Co., St. Louis, MO) was injected into the intraperitoneal space for assessment of enterocyte migration (26). Piglets were fed one third of their daily allotment of formula 2-4 h before the sample collection.

Sample collection. Piglets were killed on experimental day 10. Blood was collected in heparin-laced vials and serum separated by centrifugation $(3000 \times$ $g$ for $15 \mathrm{~min}$ at $4^{\circ} \mathrm{C}$ ). The small intestine was excised from the pyloric sphincter and the ileocecal valve, and its length was measured. The intestine was cut at 10 and $85 \%$ from the proximal end to give three segments corresponding to the duodenum, jejunum, and ileum, respectively, on the basis of distances extrapolated from Houle et al. (25). The segments were flushed with ice-cold saline and weighed. Sections of mid-jejunum and distal ileum were taken immediately for Ussing chamber analysis, frozen at $-80^{\circ} \mathrm{C}$ for RNA isolation, and preserved in a $10 \%$ buffered-formalin solution (Biochemical Sciences, Swedesboro, NJ) for immunohistochemistry. Remaining intestine was opened longitudinally, and mucosa was collected by gently scraping the luminal surface with a microscope slide and frozen at $-80^{\circ} \mathrm{C}$ for subsequent analyses.

Sample preparation. Samples were prepared according to a modified procedure of Coward et al. (27). Each serum sample $(0.5-1.0 \mathrm{~mL})$ was mixed with $1 \mathrm{~mL}$ of $0.5 \mathrm{M}$ of ammonium acetate $(\mathrm{pH} 7.2)$ and passed through a Sep-Pak tC18 cartridge (Waters, Milford, MA) equilibrated with water. After washing with $1 \mathrm{~mL}$ of water, the samples were eluted with $3 \mathrm{~mL}$ of methanol. The samples then were dried under nitrogen and resuspended in $1 \mathrm{~mL}$ of buffered enzyme solution [0.5 M of ammonium acetate ( $\mathrm{pH}$ 5.0) that contained glucuronidase type H-1 from Helix pomata (212 units/mL); Sigma Chemical Co.] and sulfatase type $\mathrm{H}-1$ from Helix pomata $(25$ units per $\mathrm{mL}$; Sigma Chemical Co.) and incubated overnight at $37^{\circ} \mathrm{C}$. The samples then were passed though through another Sep-Pak tC18 cartridge equilibrated with water, washed with water, eluted with methanol, and dried under nitrogen. The dried samples were completely resuspended in $100 \mu \mathrm{L}$ of methanol, and a $50-\mu \mathrm{L}$ sample was injected on the liquid chromatograph-mass spectrometer for analysis.

Liquid chromatography-mass spectrometry analysis. The sera samples were run on a Finnegan-Thermoquest LCQ liquid chromatography-mass spectrometry (LC-MS) system (AS3000 autoinjector, P4000 HPLC pump, UV6000 PDA detector, LCQ mass spectrometer) all running under the Xcaliber 1.2 software system. The MS ran with the ESI probe in the negative mode. The MS was optimized for the detection of isoflavone aglycones by using the autotune feature of the software while infusing a solution of daidzein in with the effluent of the column and tuning on molecular weight 254 . After injection, the column was held at the initial conditions for $2 \mathrm{~min}$, then developed with a linear gradient to $100 \% \mathrm{MeOH}(0.25 \%$ acetic acid) over $53 \mathrm{~min}$. The column effluent was monitored at $285 \mathrm{~nm}$ in the PDA detector. The software was set to collect mass data in the SIM mode for molecular weights 240-244, 252-258, 268 275 , and 282-286. The data were hand integrated at the proper retention times to determine the area for appropriate mass units. Standard curves were prepared with pure standards of equol, daidzein, glycitein, and genistein.

Electrophysiologic measurements. Mid-jejunal and ileal samples were stripped of their muscularis and mounted in modified Ussing chambers (Physiologic Instruments, San Diego, CA). Luminal and serosal surfaces $\left(0.5 \mathrm{~cm}^{2}\right)$ were exposed to oxygenated Kreb's buffer using established methods (28). Basal transmural short circuit current (Isc), resistance, and potential difference were measured and calculated. Sodium-dependent nutrient transport was measured by the change in Isc induced by the addition of either $10 \mathrm{mM}$ of glucose or glutamine to the luminal buffer. Chloride secretion was measured by the change in Isc induced by the addition of either $0.1 \mathrm{mM}$ of carbachol or serotonin to the serosal buffer.

Disaccharidase activity. Intestinal mucosa $(0.2 \mathrm{~g})$ was homogenized in 2 $\mathrm{mL}$ of homogenization buffer $(0.9 \%$ saline solution that contained $223 \mu \mathrm{M}$ of iodoacetic acid and $1 \mu \mathrm{M}$ of phenylmethylsulfonyl fluoride). Lactase and sucrase activities were assessed by incubating mucosal homogenates with lactose and sucrose, and glucose released from the hydrolysis of the disaccharide was detected with a glucose oxidase reagent (Glucose Trinder; Sigma Chemical Co.) (29). Protein content was determined from the same homogenized mucosa by a modified Lowry assay (30). Disaccharidase activity was expressed as the amount of glucose released per minute per gram of protein.

Mucosal DNA. DNA content was determined fluorometrically with Hoescht $\mathrm{H} 33258$ dye (31). Fluorescence was measured at excitation wavelength of $365 \mathrm{~nm}$ and emission wavelength of $460 \mathrm{~nm}$ on Bio-Rad's VersaFluor fluorometer. DNA concentration was calculated on the basis of a standard curve using calf thymus DNA (Sigma Chemical Co.) and normalized by protein content.

Histomorphology. Formalin-fixed intestinal samples were embedded in paraffin, sliced with a microtome, and stained with hematoxylin. Intestinal images were captured with a Nikon Diaphot 200 microscope attached to a Nikon digital camera (DXM1200) connected to a computer. Villus height and width and crypt depth were measured in well-oriented villi and crypts using the software Image-Pro Express Version 4.0.1 (Media Cybernetics, Silver Spring, MD).

Enterocyte migration and proliferation. Immunohistochemistry was used to assess proliferating cells by detecting proliferating cell nuclear antigen (PCNA) and to assess the migration distances of BrdU-labeled enterocytes in $48 \mathrm{~h}$. Briefly, a series of xylene and ethanol washes were conducted to deparaffinize sections of formalin-fixed samples. After incubations in $2 \mathrm{~N}$ of 
$\mathrm{HCl}$, trypsin, and hydrogen peroxide, the sections were incubated with mouse anti-PCNA IgG antibody or mouse monoclonal anti-BrdU IgG antibody (Vector Laboratories, Burlingame, CA). Negative controls were incubated with blocking solution without the antibody. Labeled cells were detected with a biotinylated secondary antibody, horse anti-mouse IgG (Vectastain Elite ABC Kit; Vector Laboratories) and visualized using 3,3'diaminobenzidine substrate kit for peroxidase (Vector Laboratories). The slides were counterstained with Mayer's hematoxylin (Sigma Chemical Co.). Proliferation was expressed as a percentage of PCNA-positive cells per total crypt cells. Enterocyte migration distance was expressed as the distance from the bottom of the crypt to the foremost BrdU-labeled enterocyte (26).

Apoptosis. Caspase-3 is a key protease in the execution of apoptosis and an early marker of apoptosis (32). To localize where along the villus-crypt axis apoptosis was occurring, we used an antibody against cleaved caspase-3 (Cell Signaling Technology, Beverly, MA) for immunohistochemistry as described above. Negative controls were incubated with blocking solution without the anticleaved caspase-3 antibody. Apoptosis was expressed as the percentage of the villus height detected with active caspase- 3 .

$\boldsymbol{R N A}$ isolation and reverse transcription. Total RNA was isolated from the intestinal tissue $(0.1 \mathrm{~g})$ using TriZol Reagent (Invitrogen, Carlsbad, CA) and following the manufacturer's method. Subsequently, RNA samples were treated with DNase I (Invitrogen) to eliminate any DNA contamination before reverse transcription PCR (RT-PCR). The RNA was reverse-transcribed in a reaction that contained $1 \mu \mathrm{L}$ of $50 \mu \mathrm{M}$ of random decamer primers (Ambion, Austin, TX), $1 \mu \mathrm{L}$ of $10 \mathrm{mM}$ of dNTP mix (Invitrogen), $40 \mathrm{U}$ of RNaseOUT (Invitrogen), and $200 \mathrm{U}$ of SuperScript III RNase H-Reverse Transcriptase (Invitrogen).

ER- $\alpha, E R-\beta$, and trefoil factor $m \boldsymbol{R N A}$ expression. Two isoforms of ER ( $\alpha$ and $\beta$ ) are differentially distributed among the tissues (16). The pig ER- $\alpha$ and ER- $\beta$ primer sequences were from Kowalski et al. (33). The ER- $\alpha$ forward primer was 5'-ATTGGTCTTGTCTGGCGCTCC, and the reverse primer was 5'-GGTCATAGAGGGGCACCACGT (Custom Primers; Invitrogen), giving a 451-bp product. The PCR cycle protocol used for both jejunum and ileum was 32 cycles of $94^{\circ} \mathrm{C}$ for $45 \mathrm{~s}, 58^{\circ} \mathrm{C}$ for $30 \mathrm{~s}$, and $72^{\circ} \mathrm{C}$ for $30 \mathrm{~s}$. RNA isolated from sow ovary was used as a positive control for ER- $\alpha$ expression. The pig ER- $\beta$ forward primer was 5'-AGAGACATTGAAAAGGAAGG, and the reverse primer was 5'-GCCTTACATCCTTCACATGA (Custom Primers; Invitrogen), giving a 150-bp product. For jejunal samples, the PCR cycle protocol was 36 cycles of $94^{\circ} \mathrm{C}$ for $45 \mathrm{~s}, 58^{\circ} \mathrm{C}$ for $30 \mathrm{~s}$, and $72^{\circ} \mathrm{C}$ for $30 \mathrm{~s}$. For ileal samples, the cycle protocol was 36 cycles of $94^{\circ} \mathrm{C}$ for $45 \mathrm{~s}, 54^{\circ} \mathrm{C}$ for $30 \mathrm{~s}$, and $72^{\circ} \mathrm{C}$ for $30 \mathrm{~s}$.

The forward primer for pig spasmolytic polypeptide (SP)/trefoil factor 2 (TFF2) was 5'-AATTGCTGCTTCTCCGACAC, and the reverse was 5'AAACCATTGAAAAGGGCAGA, to give a 225-bp product. The PCR cycle protocol was 30 cycles of $94^{\circ} \mathrm{C}$ for $45 \mathrm{~s}, 52^{\circ} \mathrm{C}$ for $30 \mathrm{~s}$, and $72{ }^{\circ} \mathrm{C}$ for $30 \mathrm{~s}$. For porcine intestinal TFF (ITF), also known as TFF3, the amino acid sequence but not the DNA sequence was available. On the basis of the alignment of porcine and human ITF amino acid sequences and primers for human ITF obtained from Ciacci et al. (34), primers targeting porcine ITF were designed to be degenerate at bases that were not identical between porcine and humans. Primers for porcine ITF were forward 5'-GTNYTNGTGGCCTTGGCNTC and reverse 5'-TTGCAYTGYTCGGGGGTCAC, giving a 128-bp product $(\mathrm{N}=\mathrm{A}$ $+\mathrm{G}+\mathrm{C}+\mathrm{T}, \mathrm{Y}=\mathrm{C}+\mathrm{T}$ ). The PCR protocol used for jejunum was 38 cycles of $94^{\circ} \mathrm{C}$ for $45 \mathrm{~s}$ and $62^{\circ} \mathrm{C}$ for $30 \mathrm{~s}$ and for ileum was 38 cycles of $94^{\circ} \mathrm{C}$ for $45 \mathrm{~s}, 58^{\circ} \mathrm{C}$ for $30 \mathrm{~s}$, and $72^{\circ} \mathrm{C}$ for $30 \mathrm{~s}$.

PCR was performed in a $50-\mu \mathrm{L}$ reaction volume that contained $2 \mu \mathrm{L}$ of cDNA (from the resulting $\mathrm{RT}$ reaction), $1 \times$ buffer (Invitrogen), 1.5-3 $\mu \mathrm{L}$ of 50 $\mathrm{mM}$ of $\mathrm{MgCl}_{2}$ (Invitrogen), $1 \mu \mathrm{L}$ of $10 \mathrm{mM}$ of dNTP mix (Invitrogen), 1-2 $\mu \mathrm{L}$ of each primer $(10 \mu \mathrm{M}), 2 \mu \mathrm{L}$ of $18 \mathrm{~S}$ :Competimer mix (Ambion), and $2 \mathrm{U}$ of TaqDNA polymerase (Invitrogen). All PCR reactions were run with the QuantumRNA Classic or Classic II 18S standards (Ambion) to serve as the internal standard. The $18 \mathrm{~S}$ to Competimer ratio for ER- $\alpha$ was $1: 9$, for ER- $\beta$ was $0.5: 9.5$, for SP/TFF2 was $2: 8$, and for ITF/TFF3 was $1: 9$. PCR reaction $(25$ $\mu \mathrm{L})$ was loaded into a 1.5 or $2 \%$ agarose Tris-borate-EDTA gel and analyzed by gel electrophoresis. Images of the ethidium bromide-stained agarose gels were captured with the Kodak Image Station 440CF (Eastman Kodak, Rochester, NY). Net intensities of the bands were measured with Kodak 1D image analysis software. The net intensities of the bands of interest were standardized to the expression of $18 \mathrm{~S}$ rRNA.
c-Src immunoprecipitation and western immunoblot. Jejunal mucosal homogenate was centrifuged at $14,000 \times g$ at $4^{\circ} \mathrm{C}$ for $15 \mathrm{~min}$ to remove insoluble material. Protein concentration of the cleared mucosal homogenate was measured by the Lowry assay. Protein aliquots $(2 \mathrm{mg}$ ) were incubated with $3 \mu \mathrm{g}$ of c-src, a nonreceptor tyrosine kinase, antibody (Santa Cruz Biotechnology, Santa Cruz, CA) for $2 \mathrm{~h}$ at $4^{\circ} \mathrm{C}$ with gentle rocking. The c-src protein-antibody complex was precipitated by incubating with PANSORBIN Cells (Calbiochem, San Diego, CA). Proteins were resolved on precast $10 \%$ Tris-HCl mini gels (BioRad, Hercules, CA) for SDS-PAGE and then electrotransferred to nitrocellulose membranes. One membrane was blotted with c-src antibody, and another was blotted with phospho-src family (Tyr416) antibody (Cell Signaling Technology, Beverly, MA). Bound antibodies were detected using the Opti-4CN Detection Kit (BioRad), which is based on horseradish peroxidase-conjugated $2^{\circ}$ antibody for color development. Images of the nitrocellulose were captured with the Kodak Image Station 440CF, and band net intensities were measured using the Kodak 1D image analysis software.

Statistical analysis. Formula intake and body weight among the three groups were compared each day. The other assessments were day 10 measurements, and comparisons among the groups within either jejunum or ileum were made using one-way ANOVA under the GLM procedure looking at the main effect of diet. Probabilities for all pair-wise differences were computed with the PDIFF option (SAS v.8e; SAS Institute, Cary, NC). Statistical significance was set at $p \leq 0.05$, and trends were reported at $p \leq 0.1$. Data are reported as mean $\pm \mathrm{SD}$.

\section{RESULTS}

Piglet growth and milk consumption. Piglet absolute body weight and weight gain did not differ among the groups. At experimental day 10 , the average body weights of the piglets in the MR $(n=8), \mathrm{LG}(n=7)$, and $\mathrm{HG}(n=8)$ groups were 3.0 $\pm 0.7,3.1 \pm 0.6$, and $3.0 \pm 0.3 \mathrm{~kg}$, respectively. The average weight gain was $1.3 \pm 0.5(\mathrm{MR}), 1.4 \pm 0.4(\mathrm{LG})$, and $1.3 \pm$ $0.3 \mathrm{~kg}(\mathrm{HG})$. The volume of formula consumed per day by the piglets was not significantly different among the groups. By day 2 , the piglets had learned to self-feed and consumed close to the allotted $360 \mathrm{~mL} / \mathrm{kg}$ body weight each day. By the last day, the MR, LG, and HG groups consumed $961 \pm 229,993$ $\pm 202,958 \pm 90 \mathrm{~mL}$, respectively.

Serum genistein. Genistein was detected in the sera of the piglets by LC-MS (Fig. 1). The piglets absorbed genistein as indicated by the $\sim 200$-fold rise in serum genistein concentration in the HG group compared with the MR control (Fig. 2). The HG group achieved serum concentrations within the range reported in human infants who are fed soy formula (4). Serum genistein of the LG group did not differ significantly from the MR group. The mean concentrations of genistein in the serum of the MR, LG, and HG groups were $0.01 \pm 0.02,0.07 \pm 0.07$, and $2.36 \pm 2.26 \mu \mathrm{M}$, respectively

Small intestinal weight and length. No significant differences were detected in intestinal weight and length among the groups. Mean intestinal weight was $47.3 \pm 7.3,47.4 \pm 2.9$, and $47.3 \pm 3.2 \mathrm{~g} / \mathrm{kg}$ body weight and mean intestinal length was $223.5 \pm 28.3,217.5 \pm 23.9$, and $226.3 \pm 14.6 \mathrm{~cm} / \mathrm{kg}$ body weight for the MR, LG, and HG groups, respectively.

Histomorphology. There were no significant differences in jejunal histomorphology. Mean villus height $(\mu \mathrm{m})$ was 1277.2 $\pm 377.8(\mathrm{MR}), 1132.1 \pm 317.8(\mathrm{LG})$, and $1117.1 \pm 280.7$ (HG); villus width $(\mu \mathrm{m})$ was $169.7 \pm 17.1(\mathrm{MR}), 183.9 \pm 11.8$ (LG), and 185.1 \pm 34.8 (HG); and crypt depth $(\mu \mathrm{m})$ was 267.9 $\pm 49.3(\mathrm{MR}), 287.0 \pm 67.4(\mathrm{LG})$, and $248.9 \pm 30.7(\mathrm{HG})$. 


\section{SIM trace (mass $=269)$}
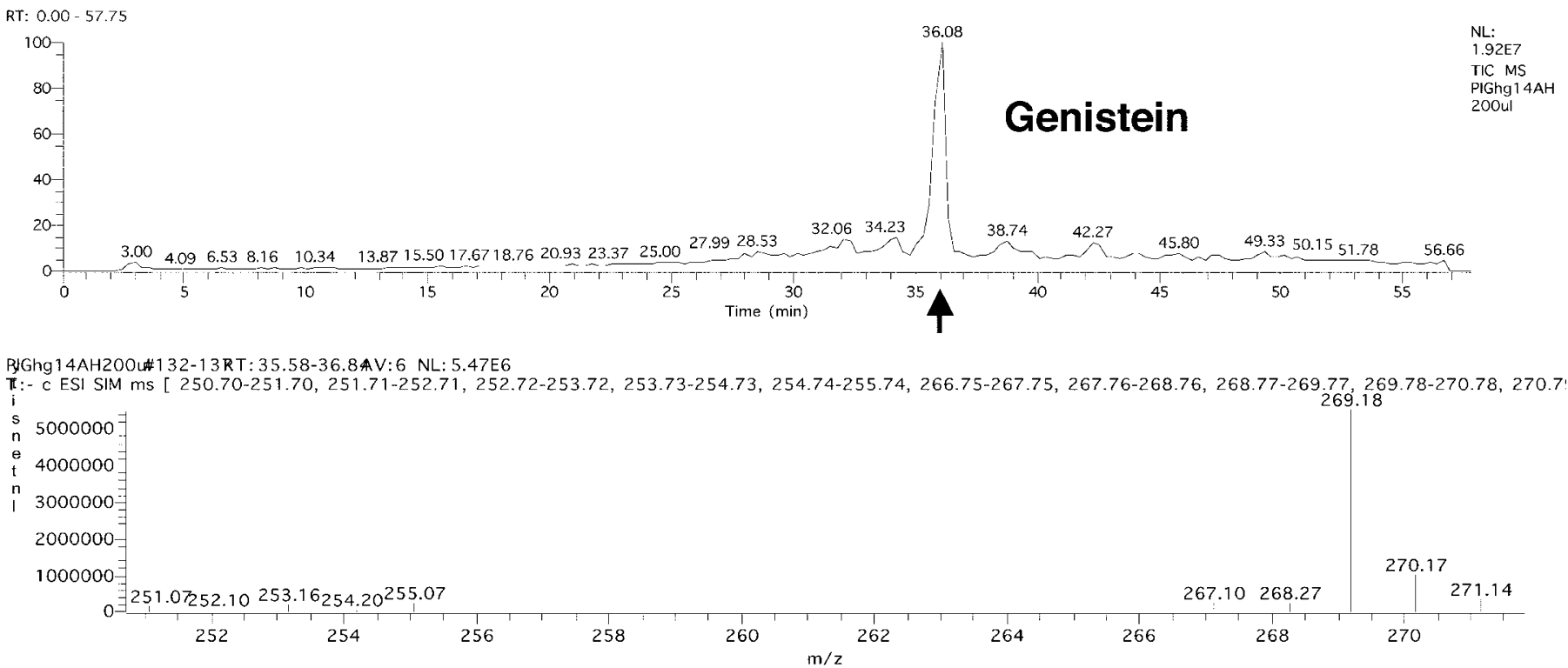

\section{Mass spectra at Rt 35-5-36.5}

Figure 1. LC-MS ESI-SIM analysis of hydrolyzed serum from a pig that was fed genistein. The MS was optimized for the detection of isoflavone aglycones by using the autotune feature of the software while infusing a solution of genistein with the effluent of the column and tuning on molecular weight 269 . The software package was set to collect mass data in the SIM mode for molecular weight 269. A standard curve was prepared with a pure standard of genistein. An extinction coefficient on a nanomolar basis was obtained from the standard curve to determine the concentrations of genistein in the sera. Background levels were very high. An average background was determined from the control pig sera runs and subtracted from each integrated value.

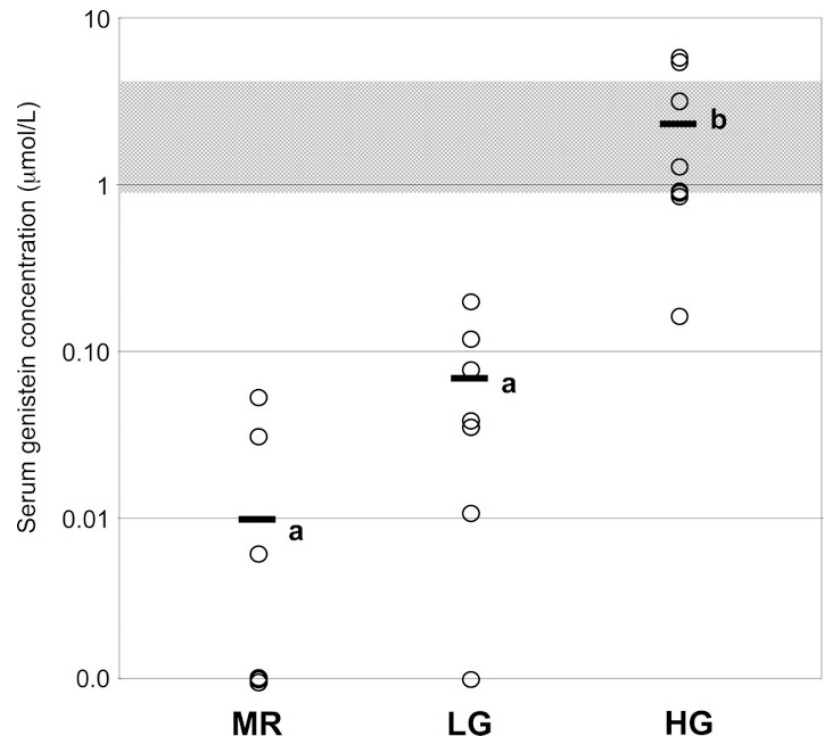

Figure 2. Serum genistein concentrations of piglets that were fed 0,1 , or 14 $\mathrm{mg} / \mathrm{L}$ of genistein for $10 \mathrm{~d}$. Serum genistein concentrations at experimental day 10 of each piglet within each group is shown. On average, serum genistein in the HG group $(n=8)$ was significantly higher than the MR control $(n=7)$ and LG $(n=$ 7 ) groups. The shaded region is the plasma genistein concentration (mean $\pm 1 \mathrm{SD}$ ) of soy formula-fed infants as reported by Setchell et al. (4). The HG group had serum genistein concentration similar to that in soy formula-fed infants, suggesting that the genistein dose that we used was clinically relevant. Different superscripts indicate significant differences at $p \leq 0.05$.

Electrophysiologic measurements. Data from the Ussing chambers revealed no significant differences in passive or active ion transport, sodium-coupled glucose or glutamine transport, or secretagogue-induced ion transport in either the jejunum or the ileum (Table 1).

Disaccharidase activities, protein, and DNA content. Jejunal disaccharidase activity was unaffected by genistein consumption. Mean lactase and sucrase activities for MR, LG, and HG were $201 \pm 61,213 \pm 9$, and $217 \pm 115 \mu$ mol glucose .

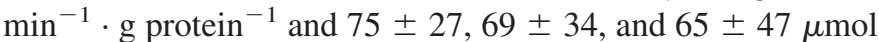
glucose $\cdot \min ^{-1} \cdot g$ protein ${ }^{-1}$, respectively. Last, the groups showed no significant differences in protein content $(9.0 \pm 1.6$, $9.2 \pm 1.6$, and $8.8 \pm 1.3 \mathrm{mg} / \mathrm{mL}$ mucosal homogenate in MR, LG, and HG, respectively) or DNA (63 $\pm 13,67 \pm 9$, and 64 $\pm 8 \mu \mathrm{g} / \mathrm{mg}$ protein in MR, LG, and HG, respectively).

Enterocyte proliferation and migration. PCNA-stained cells and nonstained cells in well-oriented crypts were counted. The HG group displayed approximately half the percentage of PCNA-positive cells (12 $\pm 6 \%$; Fig. 3) compared with the MR $(24 \pm 7 \%)$ and LG $(26 \pm 7 \%)$ groups. There was a trend for the enterocyte migration distance in the HG group to be $20 \%$ less than the MR and LG groups, compared with MR (Fig. 4). The migration distance in the MR, LG, and HG groups was $596.1 \pm 140.0,577.4 \pm 75.2$, and $468.8 \pm 30.8 \mu \mathrm{m}$, respectively.

Apoptosis. Active caspase- 3 was detected at the tips of the intestinal villi (Fig. 5). The distance from the tip of the villus to the end of the active caspase- 3 staining along the length of the villus was measured and defined as the apoptotic distance and then expressed as a percentage of the villus height. The percentage of the villus height that underwent apoptosis in the $\mathrm{MR}, \mathrm{LG}$, and $\mathrm{HG}$ group was $19.6 \pm 7.1 \%, 18.1 \pm 3.4 \%$, and 
Table 1. Ion transport, sodium-coupled glucose and glutamine transport, and chloride secretion in d 10 piglets consuming milk replacer formula supplemented with genistein

\begin{tabular}{lccc}
\hline & MR & Low Genistein & High Genistein \\
\hline JEJUNUM & $75.54 \pm 46.33$ & $50.45 \pm 15.92$ & $59.62 \pm 30.85$ \\
Transmucosal resistance $\left(\Omega / \mathrm{cm}^{2}\right)$ & $27.07 \pm 16.41$ & $48.77 \pm 17.60$ & $48.64 \pm 23.81$ \\
Basal ISC $\left(\mathrm{mA} / \mathrm{cm}^{2}\right)$ & $1.74 \pm 0.90$ & $2.35 \pm 0.70$ & $2.55 \pm 0.95$ \\
Potential difference $(\mathrm{mV})$ & $13.33 \pm 15.70$ & $27.95 \pm 8.78$ & $21.97 \pm 8.58$ \\
Glucose transport $\left(\Delta \mathrm{Isc} / \mathrm{cm}^{2}\right)$ & $3.91 \pm 2.25$ & $6.09 \pm 3.93$ & $7.04 \pm 3.87$ \\
Glutamine transport $\left(\Delta \mathrm{Isc} / \mathrm{cm}^{2}\right)$ & $13.52 \pm 9.89$ & $12.48 \pm 4.58$ & $21.56 \pm 16.43$ \\
Carbachol-induced chloride secretion $\left(\Delta \mathrm{Isc} / \mathrm{cm}^{2}\right)$ & $13.52 \pm 9.89$ & $12.48 \pm 4.58$ & $21.56 \pm 16.43$ \\
Seratonin-induced chloride secretion $\left(\Delta \mathrm{Isc} / \mathrm{cm}^{2}\right)$ & $8.35 \pm 9.39$ & $5.53 \pm 2.98$ & $8.14 \pm 6.26$ \\
ILEUM & & & \\
Transmucosal resistance $\left(\Omega / \mathrm{cm}^{2}\right)$ & $53.10 \pm 20.68$ & $90.03 \pm 70.73$ & $82.31 \pm 45.54$ \\
Basal ISC $\left(\mathrm{mA} / \mathrm{cm}^{2}\right)$ & $29.62 \pm 30.91$ & $0.88 \pm 0.94$ & $5.25 \pm 7.65$ \\
Potential difference $(\mathrm{mV})$ & $1.18 \pm 0.96$ & $24.58 \pm 22.24$ & $0.54 \pm 0.68$ \\
Glucose transport $\left(\Delta \mathrm{Isc} / \mathrm{cm}^{2}\right)$ & $54.11 \pm 52.95$ & $6.80 \pm 5.72$ & $32.31 \pm 20.01$ \\
Glutamine transport $\left(\Delta \mathrm{Isc} / \mathrm{cm}^{2}\right)$ & $12.35 \pm 13.96$ & $4.17 \pm 3.62$ & $5.71 \pm 5.18$ \\
Carbachol-induced chloride secretion $\left(\Delta \mathrm{Isc} / \mathrm{cm}^{2}\right)$ & $3.16 \pm 4.51$ & $1.11 \pm 1.07$ & $2.86 \pm 4.77$ \\
Seratonin-induced chloride secretion $\left(\Delta \mathrm{Isc} / \mathrm{cm}^{2}\right)$ & $4.40 \pm 6.09$ & & $1.57 \pm 1.64$ \\
\hline
\end{tabular}

Data expressed as mean $\pm \mathrm{SD}$.

$N=6-8$ piglets per data point.

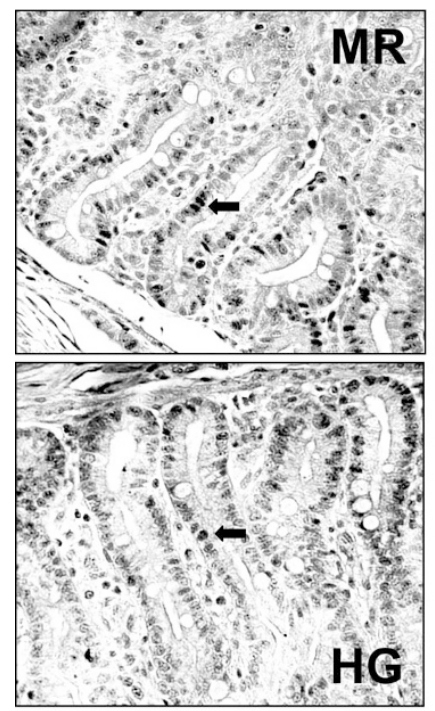

$* \mathrm{P}=0.001$

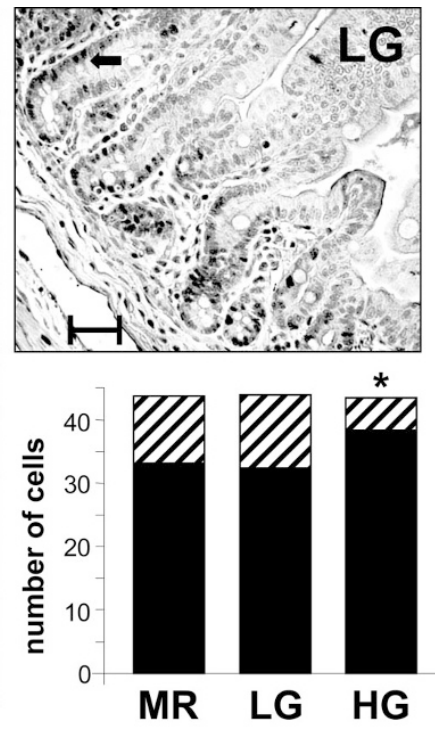

MR LG HG

Figure 3. Immunohistochemical detection of PCNA in jejunal crypts of piglets that were fed $0(n=8), 1(n=7)$, or $14(n=8) \mathrm{mg} / \mathrm{L}$ of genistein for $10 \mathrm{~d}$. Proliferation was assessed by detecting PCNA-positive cells through immunohistochemistry. Piglets in all groups had on average the same number of cells in the crypt. The high dose of genistein reduced the number of proliferating cells in the jejunal crypts by half $\left({ }^{*} p=0.001\right)$, indicating decreased proliferation. The number of PCNA-positive cells in the MR and LG groups was not significantly different. Magnification: $\times 40$. Scale bar $=10 \mu \mathrm{m}$.

$22.0 \pm 9.7 \%$, respectively. There were no significant differences among the groups.

ER- $\alpha, E R-\beta$, and TFF mRNA expression. Expression of ER- $\alpha$ mRNA was relatively low in the small intestine, especially in young piglets. ER- $\alpha$ expression in the day 10 jejunum and ileum was only 2 and 7\%, respectively, of the expression in the ovary of a sow (positive control). There were no significant differences in ER- $\alpha$ expression in the ileum among $\mathrm{MR}, \mathrm{LG}$, and $\mathrm{HG}(0.91 \pm 0.57,1.13 \pm 0.51,0.84 \pm 0.46$ densitometric units, respectively). ER- $\alpha$ expression was ex-
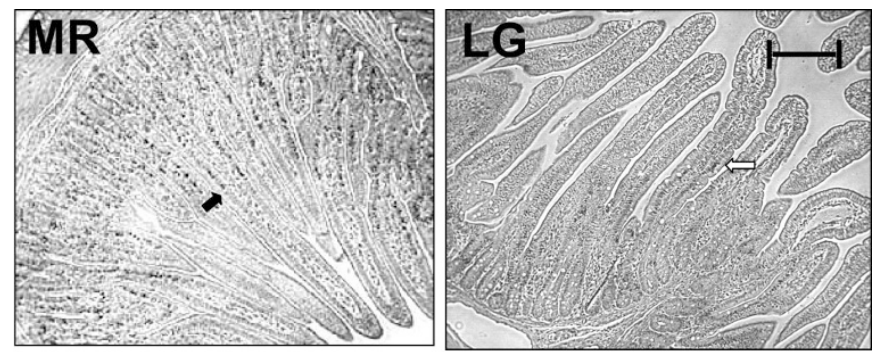

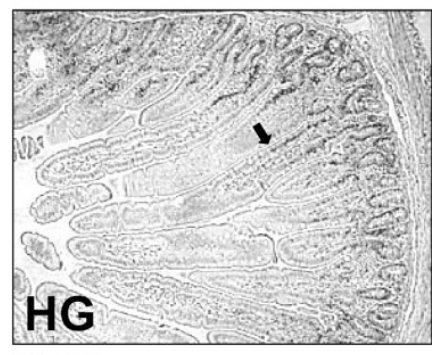

$\$ \mathrm{P}=0.1$

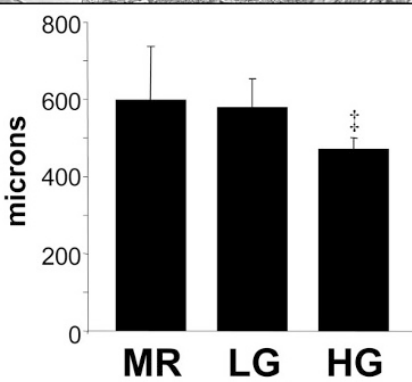

Figure 4. Immunohistochemical detection of BrdU incorporation into jejunal enterocytes in piglets that were fed $0(n=5), 1(n=4)$, or $14(n=5) \mathrm{mg} / \mathrm{L}$ of genistein for $10 \mathrm{~d}$. The piglets received an injection of $50 \mathrm{mg} / \mathrm{kg}$ body weight of BrdU into the intraperitoneal space $48 \mathrm{~h}$ before the killing to assess enterocyte migration. Enterocytes that incorporated BrdU were detected by immunohistochemistry. The migration distance was measured as the distance from the bottom of the crypt to the foremost labeled enterocyte. There was the tendency ( $\downarrow p=0.1$ ) for the high dose of genistein to suppress enterocyte migration as indicated by the lower migration distance in the HG group compared with the MR and LG groups. Data are mean \pm SD. Magnification: $\times 10$. Scale bar $=100 \mu \mathrm{m}$.

tremely low in the jejunum; differences could not be reliably assessed.

ER- $\beta$ mRNA expression was readily detectable in piglet intestine. On average, jejunal ER- $\beta$ expression in the LG group was $18 \%$ greater than in the MR group, whereas jejunal ER- $\beta$ expression in the HG group was $40 \%$ lower than in the MR group (Fig. 6), but neither was significantly different from the MR group. However, expression of ER- $\beta$ in the HG group was $50 \%$ lower than that in the LG group $(p=0.05)$. In the ileum, 


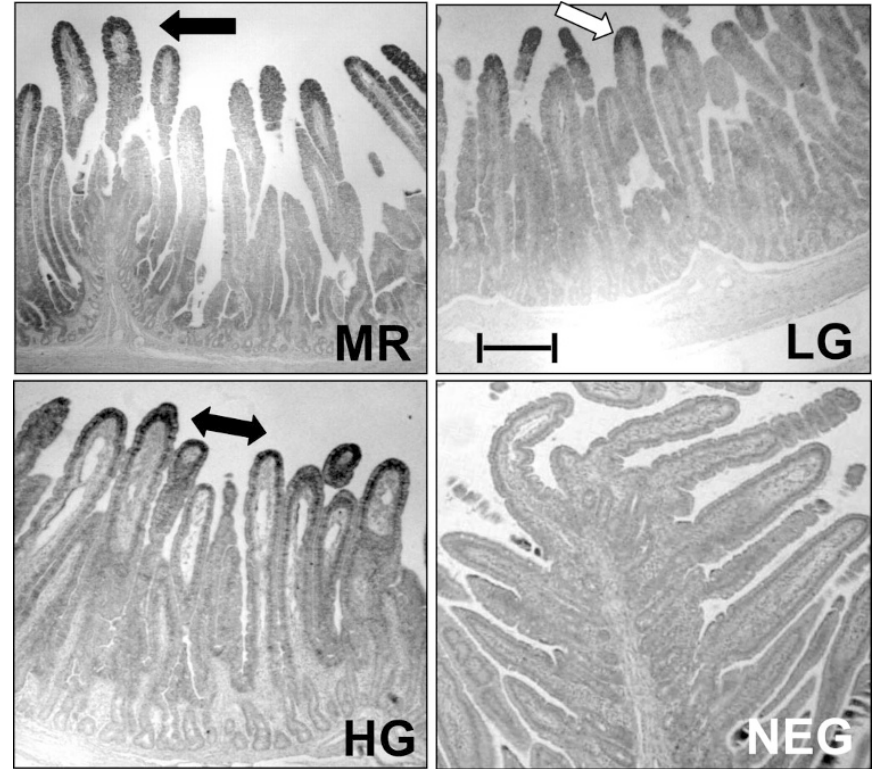

Figure 5. Immunohistochemical detection of cleaved (active) caspase- 3 in jejunum of piglets that were fed $0(n=5), 1(n=6)$, or $14(n=6) \mathrm{mg} / \mathrm{L}$ of genistein for $10 \mathrm{~d}$. Detecting active caspase- 3 through immunohistochemistry was used to assess apoptosis along the villus. Apoptosis was detected mainly at the tips of the villi. There were no significant differences in the percentage of the villus height that underwent apoptosis in the jejunum among the groups. Magnification: $\times 10$. Scale $\mathrm{bar}=100 \mu \mathrm{m}$.

there were no significant differences in ER- $\beta$ expression among the groups (Fig. 6).

SP/TFF2 expression in the stomach was $\sim 33 \%$ lower $(p=$ 0.05 ) in both LG and HG groups compared with the control (Fig. 7). On average, jejunal ITF expression in the MR, LG, and $\mathrm{HG}$ groups was $0.30 \pm 0.16,0.24 \pm 0.09$, and $0.18 \pm 0.04$ densitometric units, respectively (Fig. 7). There were no significant differences among the groups. Ileal ITF expression was $0.45 \pm 0.23,0.41 \pm 0.13$, and $0.58 \pm 0.22$ densitometric units in the MR, LG, and HG groups, respectively (Fig. 7). Again, there were no significant differences among the groups.

c-Src immunoprecipitation and Western immunoblot. There were no significant differences in c-src protein abun-
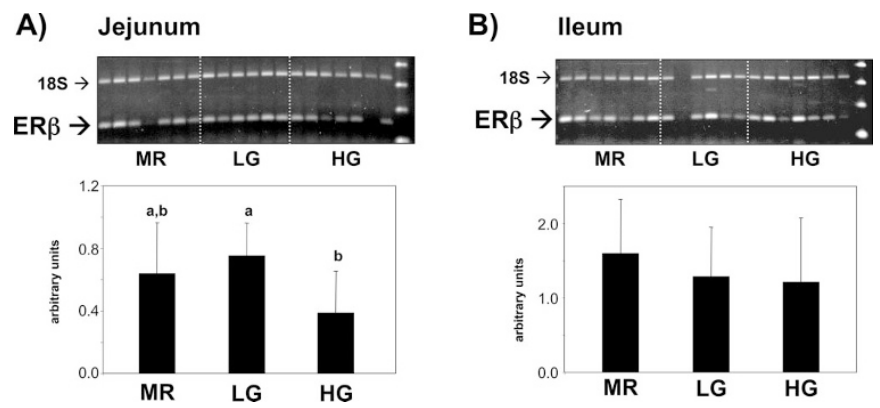

Figure 6. Jejunal and ileal ER- $\beta$ mRNA expression by RT-PCR in piglets that were fed $0(n=7), 1(n=6)$, or $14(n=7) \mathrm{mg} / \mathrm{L}$ of genistein for $10 \mathrm{~d}$. (A) Jejunal ER- $\beta$ expression in HG was half that in LG. However, neither genistein groups had significantly different ER- $\beta$ expression compared with the MR group. ( $B$ ) Ileal ER- $\beta$ expression was not significantly different among the groups. The $18 \mathrm{~S}$ band is $324 \mathrm{bp}$. The ER- $\beta$ band is $150 \mathrm{bp}$. Data are mean \pm SD. Different superscripts indicate significant differences at $p \leq 0.05$.
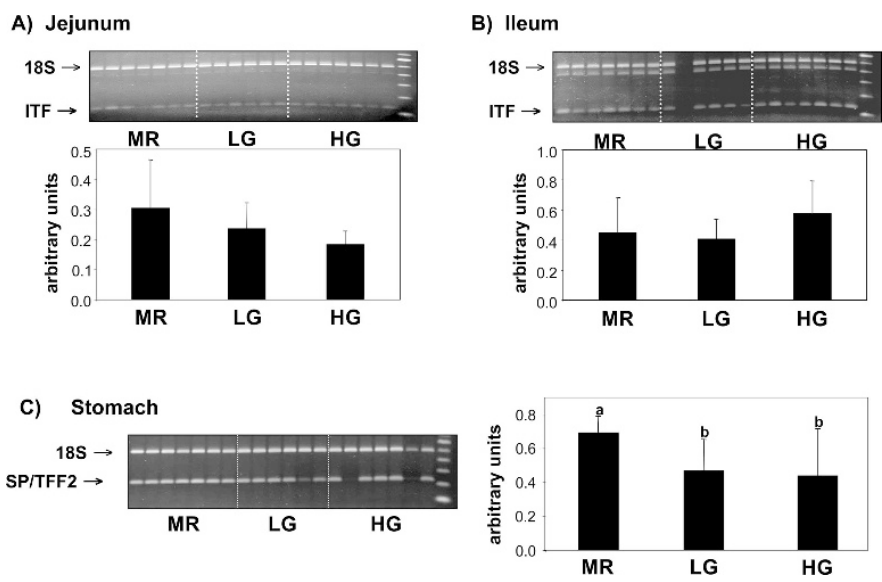

Figure 7. Jejunal and ileal ITF mRNA expression and stomach SP/TFF2 mRNA expression by RT-PCR in piglets that were fed $0(n=7), 1(n=6)$, or $14(n=7) \mathrm{mg} / \mathrm{L}$ of genistein for $10 \mathrm{~d}$. There were no significant differences in ITF expression among the groups in the jejunum $(A)$ or the ileum $(B)$. The $18 \mathrm{~S}$ band is $489 \mathrm{bp}$. The ITF band is $128 \mathrm{bp}$. (C) SP/TFF2 expression in the stomach was approximately one third lower in the LG and HG groups compared with the control group. Data are mean \pm SD. Different superscripts indicate significant differences at $p \leq 0.05$.

dance among the groups (Fig. 8). Active c-src (phospho-src Tyr416) protein levels were also not significantly different among the groups (Fig. 8).

\section{DISCUSSION}

Nearly one quarter of all formula-fed infants in the United States are fed soy formula (2) and consequently exposed to high doses of genistein. Concerns have been voiced regarding the high circulating concentrations of isoflavones observed in infants who are fed soy formula and their potential impact on reproductive and immune development (35-37). However, little attention has been given to the potential impact of luminal exposure to genistein on intestinal development and function of infants. When infants consume soy formula, the gastrointestinal tract is the first organ to be exposed to isoflavones and thus is susceptible to their estrogenic and antiproliferative effects. Soy-based infant formulas support normal growth for the first full year of life in healthy term infants (38), although the incidence of physician-reported but not parent-reported diarrhea was greater in infants who were fed soy-based infant formulas than human milk or cow milk-based formula (39). Nevertheless, direct clinical or experimental studies investigating outcomes related to intestinal development or function of soy formula-fed infants are lacking. Thus, the goal of the current study was to investigate the impact of genistein on neonatal intestinal structure and function in a piglet model.

Because of the complexity of the ingredients within soy formula that might affect intestinal development, the current investigation was designed to focus on the specific impact of genistein on intestinal development of piglets. Piglets were fed formula that contained 1 or $14 \mathrm{mg} / \mathrm{L}$ of genistein. The $14-\mathrm{mg} / \mathrm{L}$ concentration was calculated as the genistein equivalents (genistein + genistin) present in soy formula. The $1-\mathrm{mg} / \mathrm{L}$ concentration had been shown previously to stimulate proliferation of cultured enterocytes (22), and it could be achieved in 
A) IP: c-src Blot: c-src

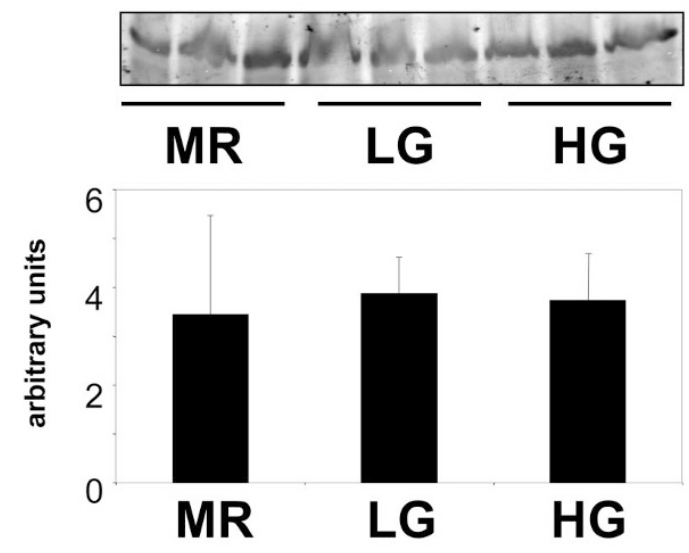

B)

IP: c-src

Blot: phospho-src family (Tyr416)

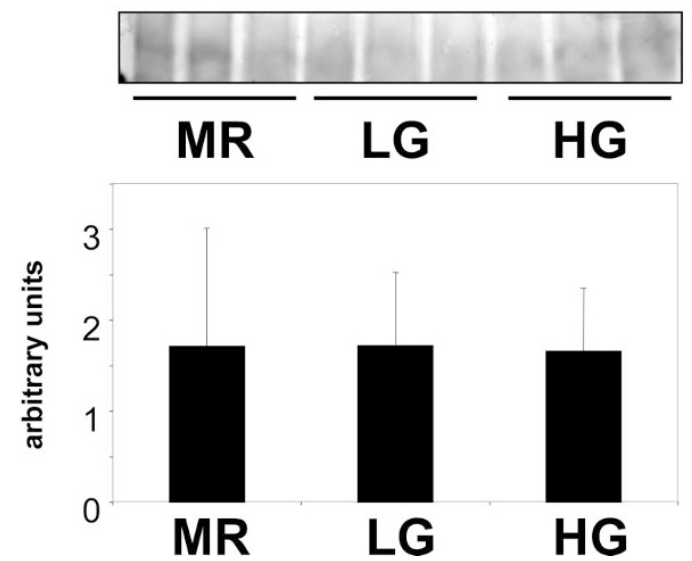

Figure 8. c-src and phospho-src family (Tyr416) protein levels in jejunal mucosa of piglets that were fed $0(n=6), 1(n=6)$, or $14(n=6) \mathrm{mg} / \mathrm{L}$ of genistein for $10 \mathrm{~d}$. Protein levels of c-src $(A)$ and phospho-src (Tyr416; $B)$ were not significantly different among the groups. Data are mean $\pm \mathrm{SD}$.

an infant formula prepared with isoflavone-reduced soy protein isolate. Neither dose of genistein affected the growth of piglets, which corresponds to normal growth in soy formula-fed infants. Although piglets received the aglycone genistein rather than the $\beta$-glucoside form genistin that is the predominant isoflavone in soy formula, mean serum genistein concentration in piglets that were fed the high genistein formula was $2.36 \pm$ $2.26 \mu \mathrm{M}$. This concentration was nearly identical to that reported in human infants who were fed a soy protein formula $(2.53 \pm 1.64 \mu \mathrm{M})$ by Setchell et al. (4). These data suggest that human infants have sufficient $\beta$-glucosidase activity to efficiently hydrolyze genistin in soy formula to genistein. Furthermore, these data show that the amount of genistein fed to the piglets was physiologically relevant and that the piglet may be a good model to investigate potential systemic effects of dietary isoflavones on developing organs and tissues.

ERs are present in intestines of pigs and other species (14-16); however, modulation of intestinal ER expression by genistein had not been investigated previously. ER- $\beta$ is the main form of ER expressed in the gastrointestinal tract (40) and has an affinity for genistein $>10$-fold (41) higher than that of ER- $\alpha$ for genistein. We observed very low expression of ER- $\alpha$ in the intestine of the piglets, and its expression was unaffected by dietary genistein. ER- $\beta$ expression in the jejunum or ileum was not significantly affected by the addition of genistein to the diet when compared with the MR group. However, ER- $\beta$ mRNA expression in the jejunum of piglets that were fed the HG formula was $50 \%$ that of piglets that were fed the LG formula. Genistein modulation of ER- $\beta$ expression is also evident in other tissues $(42,43)$.

Our results demonstrate that genistein retains bioactivity within the neonatal gastrointestinal tract and affects cells that are located within the intestinal crypts to a greater degree than the fully differentiated cells that are located on the villi. Piglets that consumed formula that contained $14 \mathrm{mg} / \mathrm{L}$ of genistein for $10 \mathrm{~d}$ had reduced enterocyte proliferation and migration. However, villus height and overall intestinal growth were unaffected. The PCNA results are indicative of the level of proliferation occurring at the time the intestine was collected and is not necessarily reflective of what occurred throughout the $10 \mathrm{~d}$. We collected intestinal samples at experimental day 2, and there was no significant difference in proliferation between the control and HG groups at that time (data not shown). Thus, the reduction in crypt cell proliferation had occurred for $8 \mathrm{~d}$ or less before sample collection, which perhaps is why villus morphology had not been significantly affected.

The inhibition of intestinal cellular proliferation by genistein in vivo supports that observed in vitro by our group (22) and others $(19,20,44)$. In vitro studies have delineated a possible mechanism underlying the biphasic effects of genistein for cell proliferation. At low concentrations, genistein, acting through the ER, stimulates c-src, a nonreceptor tyrosine kinase, and activates erk-1 and erk- 2 of the mitogen-activated protein kinase pathway to stimulate growth $(45,46)$. However, at higher concentrations, genistein can act through non-ERmediated events such as inhibiting tyrosine kinase activation of c-src, which leads to downstream inactivation of erk-2 activity and results in a decline in proliferation $(45,46)$. Eventually, cells accumulate in $\mathrm{G} 2 / \mathrm{M}$, resulting in G2/M cell-cycle arrest (22). In the current study, we did not observe c-src inactivation in the jejunum of the piglets in the HG group. However, the transient nature of signaling activation (46) could explain the lack of observation because jejunal samples were collected 2-4 $\mathrm{h}$ after the piglets were fed the treatment formula.

At the genistein concentration used in the LG group of the current study, intestinal cell proliferation was enhanced in vitro (22). Genistein mediated intestinal cell proliferation through the ER, as the addition of the pure antiestrogen ICI 182,780 to the culture media negated the increased proliferation induced by a low dose of genistein (22). We observed no significant difference in intestinal cell proliferation of piglets that were fed formula that contained $1.0 \mathrm{mg} / \mathrm{L}$ of genistein compared with formula alone. It is possible that endogenous gastrointestinal secretions diluted genistein below a concentration that would stimulate cell proliferation in vivo. 
Genistein also has apoptotic effects that can contribute to a decrease in proliferation in the intestine. In HT-29 cells, a 4-d exposure to 60 and $150 \mu \mathrm{M}$ of genistein resulted in 54 and $94 \%$ apoptotic cells, respectively (47). We assessed apoptosis by detecting active caspase-3, a key protease in the execution of apoptosis and an early marker of apoptosis (32), through immunohistochemistry and found active caspase- 3 localized to enterocytes mainly at the tips of the villi, where it has also been reported by other laboratories $(48,49)$. There was no effect of dietary genistein on expanding the apoptotic zone along the villus height.

We observed a trend for enterocyte migration to be slower in piglets that were fed the HG formula. TFFs have a key role in mucosal repair by promoting cell migration (50). SP/TFF2 is present in the distal stomach, and ITF (ITF/TFF3) is expressed throughout the small and large intestine (51). ITF expression was previously shown to be induced by estradiol (52); thus, we sought to determine whether genistein modulated the expression of ITF in the small intestine and SP/TTF2 in the stomach. ITF expression in the jejunum and the ileum was not affected. The observed trend in suppressed enterocyte migration in the jejunum was not attributable to a change in ITF expression. The lower cell proliferation in the jejunal crypts most likely led to slower replenishment of enterocytes on the villus and consequently suppressed enterocyte migration in the HG group. However, SP/TTF2 mRNA expression in the stomach of the HG piglets was one third lower than in the MR piglets, suggesting that genistein may influence gene expression in the stomach.

In addition to intestinal cell dynamics, we assessed whether dietary genistein affected intestinal digestive function. No significant effects of genistein on disaccharidase activity, nutrient transport, or other electrophysiologic measures were observed. Taken together with the inhibition of cellular proliferation, these data suggest that genistein primarily affects proliferating crypt cells rather than functionally differentiated villus epithelial cells. Consistent with these findings, we showed recently that genistein did not affect intestinal disaccharidase activity or disaccharidase mRNA expression in differentiated Caco-2BBe cells (unpublished observations). In the Caco-2 cell line, the amount of ER decreased as cells became confluent and underwent differentiation, compared with its subconfluent, undifferentiated state (53), reducing the potential for activity via the $\mathrm{ER}$ in differentiated cells.

\section{CONCLUSION}

In summary, after $10 \mathrm{~d}$ of consuming formula supplemented with genistein at the concentration present in soy-based infant formula, piglets displayed inhibited cell proliferation in the jejunal crypts and a tendency for reduced jejunal enterocyte migration. These data provide compelling evidence that genistein is bioactive within the neonatal small intestine at a concentration approximating what would be formed by conversion of the genistin in soy infant formula to genistein by intestinal $\beta$-glucosidases and lactase phlorizin hydrolase (8). Furthermore, antiproliferative effects within the intestine were observed at circulating concentrations of genistein that were comparable to those reported in human infants who were fed soy infant formula (4). On the basis of these findings, further studies of longer duration using formulas that contain mixtures of isoflavones, as well as other bioactive components in soy formulas $(54,55)$, are warranted as there are potential synergistic and opposing interactions among the various components present in soy infant formulas.

\section{REFERENCES}

1. American Academy of Pediatrics 1997 Breastfeeding and the use of human milk Pediatrics 100:1035-1039

2. American Academy of Pediatrics 1998 Soy protein-based formulas: recommendations for use in infant feeding. Pediatrics 101:148-153

3. Motil K 2000 Infant feeding: a critical look at infant formulas. Curr Opin Pediatr 12:469-476

4. Setchell KDR, Zimmer-Nechemias L, Cai J, Heubi JE 1997 Exposure of infants to phyto-oestrogens from soy-based infant formula. Lancet 350:23-27

5. Setchell KDR, Zimmer-Nechemias L, Cai J, Heubi JE 1998 Isoflavone content of infant formulas and the metabolic fate of these phytoestrogens in early life. Am J Clin Nutr 68:1453S-1461S

6. Irvine CHG, Shand N, Fitzpatrick MG, Alexander SL 1998 Daily intake and urinary excretion of genistein and daidzein by infants fed soy- or dairy-based infant formulas. Am J Clin Nutr 68:1462S-1465S

7. Ménard D 1994 Development of human intestinal and gastric enzymes. Acta Paediatr Suppl 405:1-6

8. Day AJ, Cañada FJ, Díaz JC, Kroon PA, Mclauchlan R, Faulds CB, Plumb GW, Morgan MRA, Williamson G 2000 Dietary flavonoid and isoflavone glycosides are hydrolysed by the lactase site of lactase phlorizin hydrolase. FEBS Lett 468:166-170

9. Setchell KDR 1998 Phytoestrogens: the biochemistry, physiology, and implications for human health of soy isoflavones. Am J Clin Nutr 68:1333S-1346S

10. Setchell KDR, Brown NM, Desai P, Zimmer-Nechemias L, Wolfe BE, Brashear WT, Kirschner AS, Cassidy A, Heubi JE 2001 Bioavailability of pure isoflavones in healthy humans and analysis of commercial soy isoflavone supplements. J Nutr 131:1362S-1375S

11. Andlauer W, Kolb J, Stehle P, Fürst P 2000 Absorption and metabolism of genistein in isolated rat small intestine. J Nutr 130:843-846

12. Andlauer W, Kolb J, Fürst P 2000 Isoflavones from tofu are absorbed and metabolized in the isolated rat small intestine. J Nutr 130:3021-3027

13. Morris SM, Akerman GS, Warbritton AR, Patton RE, Doerge DR, Ding X, Chen JJ 2003 Effect of dietary genistein on cell replication indices in C57BL6 mice. Cancer Lett 195:139-145

14. Ren MQ, Kuhn G, Wegner J, Nurnberg G, Chen J, Ender K 2001 Feeding daidzein to late pregnant sows influences the estrogen receptor beta and type 1 insulin-like growth factor receptor mRNA expression in newborn piglets. J Endocrinol 170:129135

15. Thomas ML, Xu X, Norfleet AM, Watson CS 1993 The presence of functional estrogen receptors in intestinal epithelial cells. Endocrinology 132:426-430

16. Gustafsson J-A 1999 Review: estrogen receptor $\beta$-a new dimension in estrogen mechanism of action. J Endocrinol 163:379-383

17. Potten CS 1998 Stem cells in gastrointestinal epithelium: numbers, characteristics and death. Phil Trans R Soc Lond B 353:821-830

18. Zava DT, Duwe G 1997 Estrogenic and antiproliferative properties of genistein and other flavonoids in human breast cancer cells in vitro. Nutr Cancer 27:31-40

19. Kuo S-M 1996 Antiproliferative potency of structurally distinct dietary flavonoids on human colon cancer cells. Cancer Lett 110:41-48

20. Dees C, Foster JS, Ahamed S, Wimalasena J 1997 Dietary estrogens stimulate human breast cells to enter the cell cycle. Environ Health Perspect 105:633-636

21. Allred CD, Ju YH, Allred KF, Chang J, Helferich WG 2001 Dietary genistin stimulates growth of estrogen-dependent breast cancer tumors similar to that observed with genistein. Carcinogenesis 22:1667-1673

22. Chen A-C, Donovan SM 2004 Genistein at a concentration present in soy infant formula inhibits $\mathrm{Caco} 2 \mathrm{BBe}$ cell proliferation by causing $\mathrm{G} 2 / \mathrm{M}$ cell cycle arrest. J Nutr 134:1303-1308

23. Moughan PJ, Birtles MJ, Cranwell PD, Smith WC, Pedraza M 1992 The piglet as a model animal for studying aspects of digestion and absorption in milk-fed human infants. World Rev Nutr Diet 67:40-113

24. Mount LE, Ingram DL 1971 The Pig as a Laboratory Animal. Academic Press, New York, pp 119-120

25. Houle VM, Schroeder EA, Odle J, Donovan SM 1997 Small intestinal disaccharidase activity and ileal villus height are increased in piglets consuming formula containing recombinant human insulin-like growth factor-I. Pediatr Res 42:78-86

26. Houle VM, Park YK, Laswell SC, Freund GG, Dudley MA, Donovan SM 2000 Investigation of three doses of oral insulin-like growth factor-I on jejunal lactase phlorizin hydrolase activity and gene expression and enterocyte proliferation and migration in piglets. Pediatr Res 48:497-503

27. Coward L, Kirk M, Albin N, Barnes S 1996 Analysis of plasma isoflavones by reversed-phase HPLC-multiple reaction ion monitoring-mass spectrometry. Clin Chim Acta 247:121-142

28. Kles KA, Wallig MA, Tappenden KA 2001 Luminal nutrients exacerbate intestinal hypoxia in hypoperfused jejunum. JPEN J Parenter Enteral Nutr 25:246-253

29. Dudley MA, Shulman RJ, Reeds PJ, Rosenberger JN, Putman M, Johnston PK, Perkinson JS, Nichols BL 1992 Developmental changes in lactase-phlorizin hydrolase precursor isoforms in the rat. J Pediatr Gastroenterol Nutr 15:260-269 
30. Peterson GL 1977 A simplification of the protein assay method of Lowry et al. which is more generally applicable. Anal Biochem 83:346-356

31. Labarca C, Paigen K 1980 A simple, rapid, and sensitive DNA assay procedure. Anal Biochem 102:344-352

32. Nicholson DW 1999 Caspase structure, proteolytic substrates, and function during apoptotic cell death. Cell Death Differ 6:1028-1042

33. Kowalski AA, Graddy LG, Vale-Cruz DS, Choi I, Katzenellenbogen BS, Simmen FA, Simmen RCM 2002 Molecular cloning of porcine estrogen receptor- $\beta$ complementary DNAs and developmental expression in periimplantation embryos. Biol Reprod 66:760-769

34. Ciacci C, Di Vizio D, Seth R, Insabato G, Mazzacca G, Podolsky DK, Mahida YR 2002 Selective reduction of intestinal trefoil factor in untreated coeliac disease. Clin Exp Immunol 130:526-531

35. Committee on Medical Aspects of Food and Nutrition Policy 1999-2000 Annual Report. Department of Health, London, pp 28-29

36. Irvine CHG, Fitzpatrick MG, Alexander SL 1998 Phytoestrogens in soy-based infant foods: concentrations, daily intake, and possible biological effects. Proc Soc Exp Biol Med 217:247-253

37. The Australian College of Paediatrics 1998 Position statement: soy protein formula. J Paediatr Child Health 34:318-319

38. Merritt RJ, Jenks BH 2004 Safety of soy-based infant formulas containing isoflavones: the clinical evidence. J Nutr 134:1220S-1224S

39. Ostrom KM, Cordle CT, Schaller JP, Winship TR, Thomas DK, Jacobs JR, Blatter MM Cho S, Gooch WM III, Granoff DM, Faden H, Pickering LK 2002 Immune status of infants fed soy-based infant formula with or without added nucleotides for 1 year: part 1 : vaccine responses and morbidity. J Pediatr Gastroenterol Nutr 34:137-144

40. Enmark E, Pelto-Huikko M, Grandien K, Lagercrantz S, Lagercrantz J, Fried G, Nordenskjold M, Gustafsson J 1997 Human estrogen receptor $\beta$-gene structure, chromosomal localization, and expression pattern. J Clin Endocrinol Metab 82:4258-4265

41. Kuiper GGJM, Lemmen JG, Carlsson B, Corton JC, Safe SH, Van Der Saag PT, Van Der Burg B, Gustafsson J 1998 Interaction of estrogenic chemicals and phytoestrogens with estrogen receptor $\beta$. Endocrinology 139:4252-4263

42. Dalu A, Blaydes BS, Bryant CW, Latendresse JR, Weis CC, Barry Delclos K 2002 Estrogen receptor expression in the prostate of rats treated with dietary genistein. J Chromatogr B Analyt Technol Biomed Life Sci 777:249-260
43. Patisaul HB, Melby M, Whitten PL, Young LJ 2002 Genistein affects ER beta- but not ER alpha-dependent gene expression in the hypothalamus. Endocrinology 143:21892197

44. Booth C, Hargreaves DF, Hadfield JA, McGown AT, Potten CS 1999 Isoflavones inhibit intestinal epithelial cell proliferation and induce apoptosis in vitro. Br J Cancer 80:1550-1557

45. Migliaccio A, Castoria G, Di Domenico M, de Falco A, Bilancio A, Lombardi M, Barone MV, Ametrano D, Zannini MS, Abbondanza C, Auricchio F 2000 Steroidinduced androgen receptor-oestradiol receptor $\beta$-Src complex triggers prostate cancer cell proliferation. EMBO J 19:5406-5417

46. Di Domenico M, Castoria G, Bilancio A, Migliaccio A, Auricchio F 1996 Estradiol activation of human colon carcinoma-derived Caco-2 cell growth. Cancer Res $56: 4516-4521$

47. Salti GI, Grewal S, Mehta RR, Das Gupta TK, Boddie AW, Constantinou AI 2000 Genistein induces apoptosis and topoisomerase II-mediated DNA breakage in colon cancer cells. Eur J Cancer 36:796-802

48. Groos S, Reale E, Luciano L 2003 General suitability of techniques for in situ detection of apoptosis in small intestinal epithelium. Anat Rec 272A:503-513

49. Grossmann J, Walther K, Artinger M, Rümmele R, Woenckaus M, Schölmerich J 2002 Induction of apoptosis before shedding of human intestinal epithelial cells. Am J Gastroenterol 97:1421-1428

50. Mashimo H, Wu DC, Podolsky DK, Fishman MC 1996 Impaired defense of intestinal mucosa in mice lacking intestinal trefoil factor. Science 274:262-265

51. Podolsky DK 2000 Mechanisms of regulatory peptide action in the gastrointestinal tract: trefoil peptides. J Gastroenterol 35:69-74

52. May FEB, Westly BR 1997 Expression of human intestinal trefoil factor in malignant cells and its regulation by oestrogen in breast cancer cells. J Pathol 182:404-413

53. Di Domenico M, Castoria G, Bilancio A, Migliaccio A, Auricchio F 1996 Estradio activation of human colon carcinoma-derived Caco-2 cell growth. Cancer Res $56: 4516-4521$

54. Wang H, Murphy PA 1994 Isoflavone content in commercial soybean foods. J Agric Food Chem 42:1666-1673

55. Rao AV, Sung MK 1995 Saponins as anticarcinogens. J Nutr 125:717S-724S 